\title{
REVIEW
}

\section{Pembaruan informasi taksonomi nyamuk dan kunci identifikasi fotografis genus nyamuk (Diptera: Culicidae) di Indonesia}

\author{
Update mosquito taxonomic information and photographic \\ identification key to mosquito (Diptera: Culicidae) \\ genera in Indonesia
}

\author{
Sidiq Setyo Nugroho*, Mujiyono \\ Balai Besar Penelitian dan Pengembangan Vektor dan Reservoir Penyakit, \\ Badan Litbang Kesehatan, Kementerian Kesehatan RI \\ Jalan Hasanudin 123, Salatiga 50271
}

(diterima Februari 2020, disetujui Oktober 2020)

\begin{abstract}
ABSTRAK
Identifikasi nyamuk betina merupakan aspek penting dalam surveilans penyakit tular vektor dan merancang strategi pengendalian vektor. Indonesia dengan keanekaragaman spesies nyamuk yang tinggi menghadapi permasalahan yang berkaitan dengan adanya beberapa penyakit tular vektor, di antaranya malaria, cikungunya, demam dengue, filariasis, dan Japanese encephalitis. Pembaruan kunci identifikasi nyamuk diperlukan untuk memberikan informasi terkini mengenai vektor penyakit di Indonesia. Saat ini, sebelum adanya publikasi daftar nyamuk Indonesia oleh O'Connor \& Sopa (1981), belum pernah ada informasi baru mengenai jumlah genus dan subgenus nyamuk di Indonesia. Tujuan artikel ini adalah menyampaikan pembaruan informasi taksonomi nyamuk dan memberikan kunci identifikasi genus nyamuk di Indonesia. Sejauh ini, terdapat 21 genus dan 63 subgenus nyamuk di negara ini. Terdapat tambahan 3 genus dan 15 subgenus dari daftar spesies tahun 1981. Genus Verrallina, Lutzia, dan Kimia adalah genus baru yang ditambahkan dalam daftar.
\end{abstract}

Kata kunci: genus, keanekaragaman, spesies, subgenus, vektor

\begin{abstract}
The adult female mosquito identification is an important aspect in vector-borne disease surveillances and vector control strategies. Indonesia with high mosquito species diversity faces the problem related to the presence of several important vector-borne diseases, including malaria, chikungunya, dengue fever, filariasis, and Japanese encephalitis. Updated key to the mosquitoes is needed to provide up to date information of the appropriate disease vectors in Indonesia. Currently, before the publication of the checklist of Indonesian mosquitoes by O'Connor \& Sopa (1981), there has been no recent information on the number of mosquito genera and subgenera in Indonesia. This article aims to deliver updates on mosquito taxonomic information and provide the identification key of the mosquito genera in Indonesia. So far, a total of 21 genera and 63 mosquito subgenera has been reported in this country. Overall there are three genera and 15 subgenera added from the 1981's mosquito checklist, Verrallina, Lutzia, and Kimia are added in the list of new mosquito genera.
\end{abstract}

Key words: diversity, genera, species, subgenera, vector

\footnotetext{
*Penulis korespondensi: Sidiq Setyo Nugroho. Balai Besar Penelitian dan Pengembangan Vektor dan Reservoir Penyakit, Badan Litbang Kesehatan, Kementerian Kesehatan RI, Jalan Hasanudin 123 Salatiga, Jawa Tengah, Indonesia 50271, Tel: 0298-327096, Faks: 0298-322604, Email: sidiqsnugroho148@gmail.com
} 


\section{PENDAHULUAN}

Penelitian mengenai keanekaragaman, persebaran, bionomik, dan peran nyamuk sebagai penular penyakit masih selalu dilaksanakan di Indonesia. Informasi tersebut sangat berguna untuk memahami hubungan antara vektor (serangga penular penyakit) dan patogennya. Khususnya, malaria dan filariasis yang saat ini sedang diupayakan percepatannya menuju status eliminasi secara nasional. Disamping malaria, penyakit tular vektor lainnya, seperti Japanese encephalitis juga mulai mendapat perhatian yang serius. Upaya pengendalian penyakit tular vektor tidak lepas dari kebutuhan data mengenai keanekaragaman spesies nyamuk. Daftar spesies nyamuk dan persebarannya di Indonesia sebelumnya pernah dirangkum pada tahun 1981 (O'Connor \& Sopa 1981).

Negara Indonesia memiliki keanekaragaman fauna yang unik karena wilayahnya terbagi dalam tiga regional sebaran fauna (zoobiogeografi), yaitu wilayah Indomalaya/Oriental, Wallacea, dan Australasia. Indonesia dilalui oleh garis Wallace yang berupa batas imajiner transisi fauna yang paling mencolok di dunia, yang bahkan lebih mencolok daripada perbedaan fauna di antara benua Afrika dan Amerika Selatan. Perbedaan fauna di lokasi yang terpisah garis Wallace tersebut tampak jelas, tidak lazim dan menuntut penjelasan sehingga tidak mengherankan jika studi biogeografi efektif dimulai dari Kepulauan Indo-Australia (Lohman et al. 2011). Konsekuensinya adalah Indonesia memiliki keanekaragaman nyamuk yang sangat tinggi, termasuk di dalamnya nyamuk vektor.

Identifikasi nyamuk yang tepat merupakan suatu keharusan dalam menentukan sebuah langkah pengendalian vektor. Selama ini praktisi entomologi maupun petugas surveilans vektor di Indonesia menggunakan kunci identifikasi genus yang diperuntukkan bagi negara lain karena kunci identifikasi nyamuk untuk Indonesia belum pernah tersedia. Kunci identifikasi yang sering digunakan di antaranya adalah karya (Stojanovich \& Scott 1965a, 1965b; 1966) untuk Vietnam (Rattanarithikul et al. 2005a, 2005b, 2007, 2006a, 2006b, 2010) dan untuk Thailand. Kedua negara tersebut terletak di wilayah Oriental sehingga kunci identifikasi tersebut tidak tepat ketika digunakan di wilayah Wallacea (misalnya Pulau Sulawesi) maupun di wilayah Australasia (misalnya di Kepulauan Maluku dan Papua) karena keanekaragaman spesies nyamuk yang sangat berbeda di antara sebelah barat (Oriental) dan timur garis Wallace. Beberapa kunci identifikasi untuk genus nyamuk Anopheles, Aedes, Culex, dan Mansonia pernah diterbitkan oleh Direktorat Jenderal Pencegahan dan Pengendalian Penyakit (O'Connor \& Soepanto 1999; Ditjen PP\&PL Depkes RI 2008a, 2008b, 2008c). Namun, kunci identifikasi untuk menentukan genus nyamuk di Indonesia belum pernah dipublikasikan.

Jumlah spesies nyamuk di Indonesia yang dirangkum oleh O'Connor \& Sopa (1981) mencatat sebanyak 456 spesies yang termasuk ke dalam 18 genus dan 48 subgenus. Selama hampir empat dekade terakhir terdapat penambahan jumlah spesies nyamuk yang berasal dari penemuan/ deskripsi spesies baru, publikasi catatan penemuan baru, perubahan taksonomi, dan pemberian status spesies bagi anggota spesies kompleks. Tujuan publikasi ini adalah menyampaikan pembaruan informasi mengenai taksonomi nyamuk dan kunci identifikasi fotografis untuk genus nyamuk di Indonesia.

\section{BAHAN DAN METODE}

\section{Pembaruan informasi taksonomi}

Informasi perkembangan taksonomi nyamuk yang diperoleh merupakan hasil tinjauan dari berbagai artikel jurnal maupun publikasi yang dirangkum dalam website taksonomi nyamuk, terutama mosquito-taxonomic-inventory.info dan mosquitocatalog.org. Informasi sebaran spesies nyamuk yang terdapat di Indonesia diperoleh dari website mosquitocatalog.org dengan kata kunci Indonesia, Borneo, dan New Guinea (Indonesia). Informasi sebaran spesies tersebut dilakukan cross check dengan publikasi dalam artikel maupun buku. Singkatan nama genus dan subgenus, serta klasifikasi tribe Aedini yang digunakan adalah klasifikasi Aedini tradisional termodifikasi menurut Wilkerson et al. (2015), yang juga telah dirangkum dalam website mosquitocatalog.org. 


\section{Penyusunan kunci identifikasi fotografis}

Foto spesimen nyamuk yang digunakan dalam kunci identifikasi merupakan spesimen awetan yang tersimpan di biorepositori Balai Besar Penelitian dan Pengembangan Vektor dan Reservior Penyakit (B2P2VRP) Salatiga. Istilah peta morfologi tubuh nyamuk dalam kunci identifikasi mengikuti glosarium Harbach \& Knight (1980).

\section{HASIL}

\section{Pembaruan informasi taksonomi}

Genus Kimia Harbach, Duc Huong \& Kitching, Lutzia Theobald, dan Verrallina Theobald adalah tiga genus baru yang ditambahkan dalam daftar genus nyamuk di Indonesia, sehingga saat ini tercatat ada 21 genus dan 63 subgenus nyamuk di Indonesia. Jumlah subgenus bertambah sebanyak 15 subgenus, rincian tersebut adalah bertambah sebanyak 18 subgenus dan berkurang tiga subgenus. Tambahan sebanyak 18 subgenus tersebut, 12 subgenus di antaranya terdapat dalam genus Aedes. Daftar genus dan subgenus nyamuk di Indonesia disampaikan dalam Tabel 1.

\section{Kunci fotografis genus nyamuk di Indonesia}

Kunci identifikasi ini disusun berdasarkan karakter 21 genus nyamuk yang telah difoto dari spesimen awetan yang tersimpan di biorepositori B2P2VRP Salatiga. Pada Gambar 1 disampaikan karakter genus nyamuk di Indonesi. Untuk membantu mengenali karakter-karakter morfologi tubuh nyamuk dalam kunci identifikasi fotografis maka disediakan Gambar 2 dan Gambar 3 yang menyajikan diagram tubuh nyamuk.

Tabel 1. Daftar genus dan subgenus nyamuk di Indonesia.

O’Connor \& Sopa (1981)

\section{Subgenus Anophelinae}

1. Genus Anopheles (2 subgenus) Subgenus Anopheles, Cellia

2. Genus Bironella (3 subgenus) Subgenus Bironella, Brugella, Neobironella
Klasifikasi saat ini

\section{$\underline{\text { Subgenus Anophelinae }}$}

1. Genus Anopheles (2 subgenus) Subgenus Anopheles, Cellia

2. Genus Bironella (3 subgenus) Subgenus Bironella, Brugella, Neobironella

\section{$\underline{\text { Subgenus Culicinae }}$}

- Tribe Aedeomyiini

3. Genus Aedeomyia

- Tribe Aedini

4. Genus Aedes (18 subgenus)

Subgenus Aedimorphus, Alanstonea, Cancraedes, Diceromyia, Edwardsaedes, Finlaya, Geoskusea, Huaedes, Lorrainea, Macleaya, Mucidus, Neomelaniconion, Ochlerotatus, Paraedes, Pseudoskusea, Rhinoskusea, Stegomyia, Verrallina

\section{Subgenus Culicinae}

- Tribe Aedeomyiini

3. Genus Aedeomyia

- Tribe Aedini

4. Genus Aedes (28 subgenus) Subgenus Aedimorphus, Alanstonea, Bruceharrisonius, Cancraedes, Christophersiomyia, Collesius, Danielsia, Downsiomyia, Edwardsaedes, Finlaya, Geoskusea, Huaedes, Hulecoeteomyia, Leptosomatomyia, Lorrainea, Macleaya, Mucidus, Neomelaniconion, Ochlerotatus, Paraedes, Patmarksia, Petermattinglyius, Phagomyia, Pseudoskusea, Rampamyia, Rhinoskusea, Scutomyia, Stegomyia

5. Genus Armigeres (2 subgenus) Subgenus Armigeres, Leicesteria

6. Genus Heizmannia (2 subgenus) Subgenus Heizmannia, Mattinglyia

6. Genus Heizmannia (2 subgenus) Subgenus Heizmannia, Mattinglyia

Dicetak tebal: genus dan subgenus yang belum tercatat dalam daftar spesies nyamuk Indonesia oleh O'Connor \& Sopa (1981); digaris bawah: subgenus yang tidak lagi tercatat dalam klasifikasi saat ini. 
Tabel 1. Daftar genus dan subgenus nyamuk di Indonesia (Lanjutan...)

\begin{tabular}{|c|c|}
\hline O’Connor \& Sopa (1981) & Klasifikasi saat ini \\
\hline \multirow{4}{*}{$\begin{array}{l}\text { - Tribe Culicini } \\
\text { 7. Genus Culex (8 subgenus) } \\
\text { Subgenus Acalleomyia, Acallyntrum, Culex, } \\
\text { Culiciomyia, Eumelanomyia, Lophoceraomyia, } \\
\text { Neoculex, Lutzia }\end{array}$} & $\begin{array}{l}\text { 7. Genus Verrallina (3 subgenus) } \\
\text { Subgenus Harbachius, Neomacleaya, } \\
\text { Verrallina }\end{array}$ \\
\hline & - Tribe Culicini \\
\hline & $\begin{array}{l}\text { 8. Genus Culex (8 subgenus) } \\
\text { Subgenus Acalleomyia, Acallyntrum, Culex, } \\
\text { Culiciomyia, Eumelanomyia, Lophoceraomyia, } \\
\text { Neoculex, Oculeomyia }\end{array}$ \\
\hline & $\begin{array}{c}\text { 9. Genus Lutzia (1 subgenus) } \\
\text { Subgenus Metalutzia }\end{array}$ \\
\hline - Tribe Ficalbiini & - Tribe Ficalbiini \\
\hline 8. Genus Ficalbia & 10. Genus Ficalbia \\
\hline $\begin{array}{l}\text { 9. Genus Mimomyia (3 subgenus) } \\
\text { Subgenus Etorleptiomyia, Ingramia, } \\
\text { Mimomyia }\end{array}$ & $\begin{array}{l}\text { 11. Genus Mimomyia (3 subgenus) } \\
\text { Subgenus Etorleptiomyia, Ingramia, Mimomyia }\end{array}$ \\
\hline - Tribe Hodgesiini & - Tribe Hodgesiini \\
\hline 10. Genus Hodgesia & 12. Genus Hodgesia \\
\hline - Tribe Mansoniini & - Tribe Mansoniini \\
\hline $\begin{array}{l}\text { 11. Genus Coquillettidia (1 subgenus) } \\
\text { Subgenus Coquillettidia }\end{array}$ & $\begin{array}{l}\text { 13. Genus Coquillettidia (1 subgenus) } \\
\text { Subgenus Coquillettidia }\end{array}$ \\
\hline $\begin{array}{l}\text { 12. Genus Mansonia ( } 1 \text { subgenus) } \\
\text { Subgenus Mansonioides }\end{array}$ & $\begin{array}{l}\text { 14. Genus Mansonia (1 subgenus) } \\
\text { Subgenus Mansonioides }\end{array}$ \\
\hline - Tribe Orthopodomyiini & - Tribe Orthopodomyiini \\
\hline 13. Genus Orthopodomyia & 15. Genus Orthopodomyia \\
\hline - Tribe Sabethini & $\begin{array}{l}\text { - Tribe Sabethini } \\
\text { 16. Genus Kimia }\end{array}$ \\
\hline 14. Genus Malaya & 17. Genus Malaya \\
\hline $\begin{array}{l}\text { 15. Genus Topomyia ( } 2 \text { subgenus) } \\
\text { Subgenus Suaymyia, Topomyia }\end{array}$ & $\begin{array}{l}\text { 18. Genus Topomyia (2 subgenus) } \\
\text { Subgenus Suaymyia, Topomyia }\end{array}$ \\
\hline $\begin{array}{l}\text { 16. Genus Tripteroides (3 subgenus) } \\
\text { Subgenus Rachionotomyia, Rachisoura, } \\
\text { Tripteroides }\end{array}$ & $\begin{array}{l}\text { 19. Genus Tripteroides (4 subgenus) } \\
\text { Subgenus Polylepidomyia, Rachionotomyia, } \\
\text { Rachisoura, Tripteroides }\end{array}$ \\
\hline - Tribe Uranotaeniini & - Tribe Uranotaeniini \\
\hline $\begin{array}{l}\text { 17. Genus Uranotaenia (2 subgenus) } \\
\text { Subgenus Pseudoficalbia, Uranotaenia }\end{array}$ & $\begin{array}{l}\text { 20. Genus Uranotaenia (2 subgenus) } \\
\text { Subgenus Pseudoficalbia, Uranotaenia }\end{array}$ \\
\hline$\underline{\text { Subgenus Toxorhynchitinae }}$ & - Tribe Toxorhynchitini \\
\hline $\begin{array}{l}\text { 18. Genus Toxorhynchites ( } 1 \text { subgenus) } \\
\text { Subgenus Toxorhynchites }\end{array}$ & $\begin{array}{l}\text { 21. Genus Toxorhinchites (1 subgenus) } \\
\text { Subgenus Toxorhynchites }\end{array}$ \\
\hline
\end{tabular}

Dicetak tebal: genus dan subgenus yang belum tercatat dalam daftar spesies nyamuk Indonesia oleh O'Connor \& Sopa (1981); digaris bawah: subgenus yang tidak lagi tercatat dalam klasifikasi saat ini. 


\section{KUNCI IDENTIFIKASI GENUS NYAMUK DI INDONESIA}

1. Probosis panjang, sangat melengkung ke bawah, dan meruncing di setengah panjangnya (1a); Tepi sayap pada ujung urat kubitus anterior (CuA) melekuk ke arah dalam (1b); Berukuran besar hingga sangat besar dan mengkilap

Toxorhynchites

Probosis tidak terlalu panjang, lurus atau sedikit melengkung, tidak meruncing di setengah panjangnya (1c); Tepi sayap pada ujung urat $\mathrm{CuA}$ tidak melekuk ke arah dalam (1d); Nyamuk berukuran kecil hingga sedang ....

2. Skutelum membulat (2a); Palpus maksila sama panjang atau hampir sama panjang dengan probosis (2b)

Skutelum dengan tiga lobi (2c); Palpus maksila panjangnya 0,7 kali panjang probosis atau kurang (2d)

3. Urat sayap median (M) dan CuA tidak bergelombang (3a)

Anopheles

Urat sayap M dan CuA tampak jelas bergelombang (3b)

Bironella

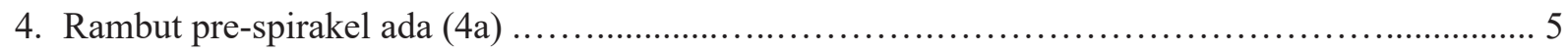

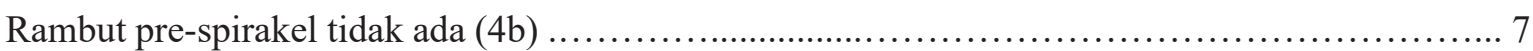

5. Skutum tanpa garis longitudinal median yang jelas dari sisik lebar berwarna keperakan, putih, atau biru metalik (5a)

Tripteroides

Skutum dengan garis longitudinal median yang jelas dari sisik lebar berwarna keperakan, putih, atau biru metalik (5b)

Malaya

6. Ujung probosis menggembung, melengkung ke atas, dan berambut (6a) 6

Ujung probosis ramping, jika sedikit menggembung maka tidak melengkung ke atas dan tidak berambut (6b)

Topomyia dan Kimia

7. Kaliptra bagian atas (upper calypter) gundul (7a) ................................................ 8

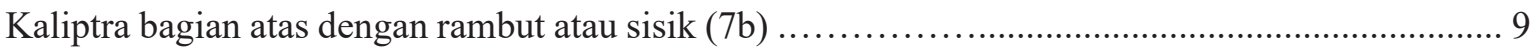

8. Urat sayap $\mathrm{R}_{2+3}$, $\mathrm{R}_{2}$ dan $\mathrm{R}_{3}$ dengan sisik tegak yang panjang dan bercabang di ujungnya (8a); Urat sayap $\mathrm{R}_{2+3}$ sama panjang atau lebih pendek daripada urat $\mathrm{R}_{2}(8 \mathrm{~b})$; Membran sayap dengan mikrotrikium yang mencolok

Hodgesia

Urat sayap $\mathrm{R}_{2+3}$, $\mathrm{R}_{2}$ dan $\mathrm{R}_{3}$ tidak ada sisik panjang, jika ada maka tidak bercabang (8c); Urat sayap $\mathrm{R}_{2+3}$ lebih panjang daripada urat $\mathrm{R}_{2}(8 \mathrm{~d})$; Membran sayap dengan mikrotrikium yang tidak mencolok

Uranotaenia

9. Ujung femur tengah dan belakang terdapat sisik membentuk bulu sikat (tuft) besar (9a); Flagelomer (segmen antena) pendek dan tebal, pangkal flagelomer dengan bulu sikat yang tampak jelas (9b) ...

Aedeomyia

Tidak ada bulu sikat besar pada ujung femur tengah dan belakang (9c); Flagelomer tidak pendek dan tebal, pangkal flagelomer tidak terdapat bulu sikat (9d)

10. Skutum dilapisi sisik lebar, bulat dan berwarna metalik (10a); Anterior pronotum biasanya besar dan terletak berdekatan $(10 \mathrm{~b})$

Heizmannia

Skutum sebagian besar dilapisi sisik sempit, jika sisik tersebut lebar maka (10c), Anterior pronotum kecil dan letaknya terpisah (10d) 
11. Tarsomer 1 kaki depan dan tengah jelas lebih panjang daripada gabungan panjang tarsomer 2-5 (11a); Panjang tarsomer 4 kira-kira sama panjang dengan lebarnya (11b); Sayap dengan pola gelap dan terang yang jelas (11c)

Orthopodomyia

Tarsomer 1 kaki depan dan tengah lebih pendek atau tidak tampak jelas lebih panjang daripada gabungan panjang tarsomer 2-5 (11d); Panjang tarsomer 4 jelas lebih panjang daripada lebarnya (11e); Sayap biasanya tidak terdapat pola gelap dan terang (11f)................................................ 12

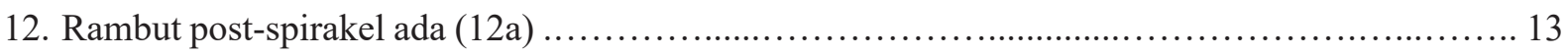

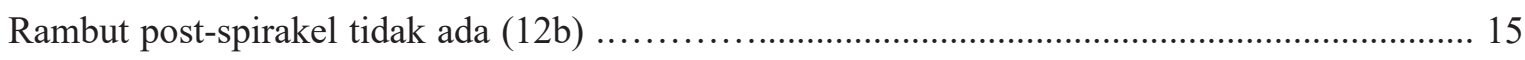

13. Sayap memiliki sisik lebar dan bentuknya asimetris, sisik berwarna gelap, dan terang bercampur (13a)

Mansonia

Sayap memiliki sisik sempit, atau jika sisiknya lebar maka simetris (13b) . 14

14. Probosis sedikit melengkung ke bawah dan pipih lateral (14a) ...... Armigeres Subgenus Armigeres Probosis tidak melengkung ke bawah, jika melengkung maka tidak pipih lateral (14b)

Aedes dan Verrallina

15. Alula gundul atau dengan sisik rebah yang lebar (15a)

Mimomyia

Alula terdapat jumbai dari sisik tegak yang sempit atau agak lebar (15b)

16. Antena dengan flagelomer 1 jelas lebih panjang daripada flagelomer 2 (16a); Palpus maksila (p) sama panjang dengan klipeus (k) (16b)

Ficalbia

Antena dengan flagelomer 1 kira-kira sama panjang dengan flagelomer 2 (16c); Palpus maksila jelas lebih panjang daripada klipeus (16d) 17

17. Biasanya tidak ada sisik pada area post-spirakel (17a) 18

Ada sisik lebar pada area post-spirakel (17b)

18. Tergum abdomen dan sayap dengan sisik berwarna ungu gelap metalik atau kuning (18a)

Coquillettidia

Tergum abdomen dan sayap tanpa sisik berwarna ungu gelap metalik atau kuning (18b) 19

19. Area post-spirakel dengan sisik hitam di bagian dorsal dan sisik putih di bagian ventral (19a); Panjang palpus maksila $0,4-0,7$ panjang probosis (19b) Armigeres subgenus Leicesteria Area post-spirakel hanya terdapat sisik putih (19c); Panjang palpus maksila kurang dari 0,4 panjang probosis (19d)

Aedes (sebagian)

20. Rambut pada mesepimeron bagian bawah tidak ada, atau jika ada paling banyak berjumlah 3 helai (20a) Culex

Rambut pada mesepimeron bagian bawah berjumlah 4 helai atau lebih (20b) Lutzia 


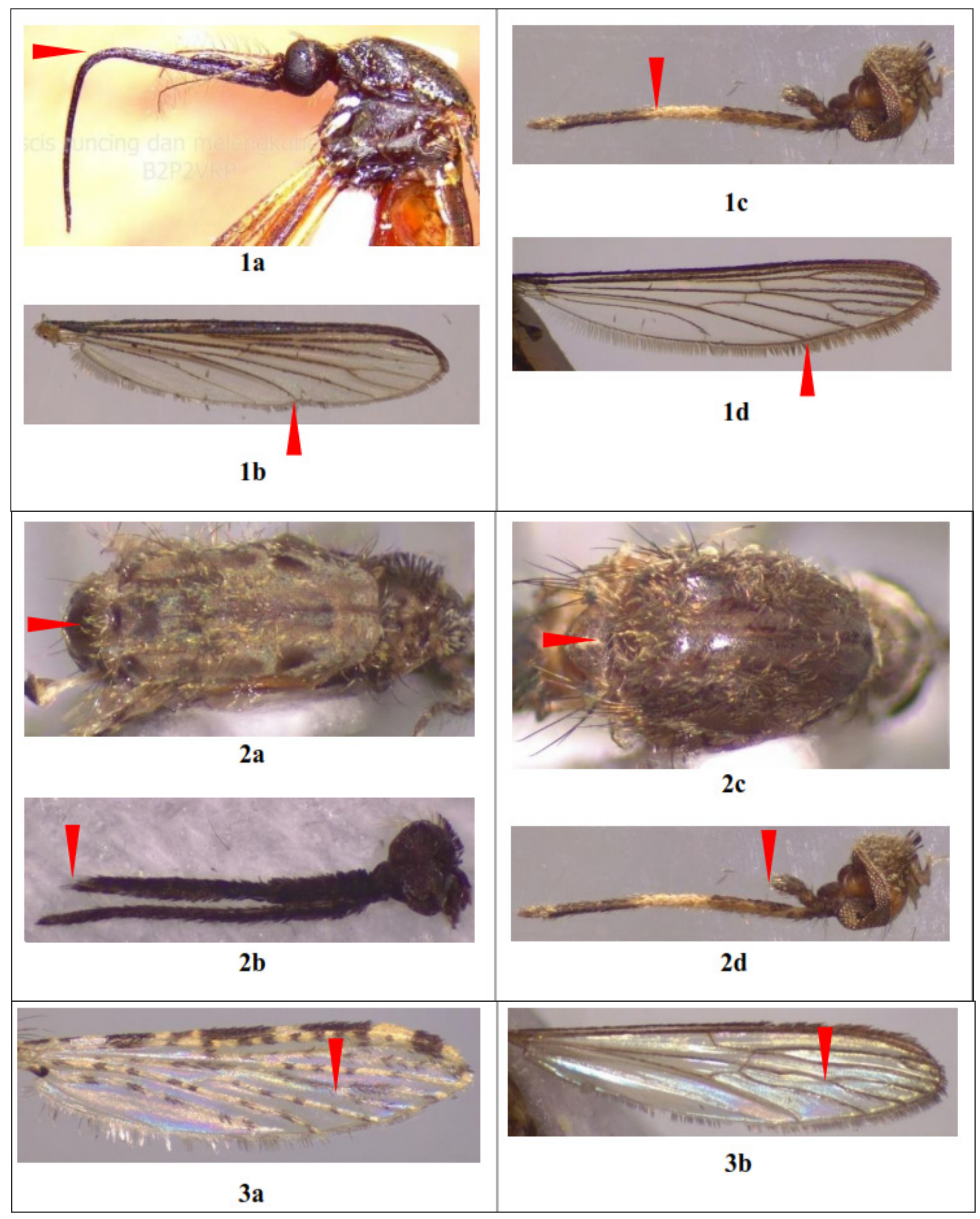

Gambar 1. Karakter genus nyamuk di Indonesia. 1a: probosis nyamuk Toxorhynchites; 1b: sayap nyamuk Toxorhynchites; 1c: probosis nyamuk; 1d: sayap nyamuk; 2a: skutum nyamuk Anophelinae; 2b: probosis-palpus nyamuk Anophelinae; 2c: skutum nyamuk Culicinae; 2d: probosis-palpus nyamuk Culicinae; 3a: sayap nyamuk Anopheles; 3b: sayap nyamuk Bironella. 


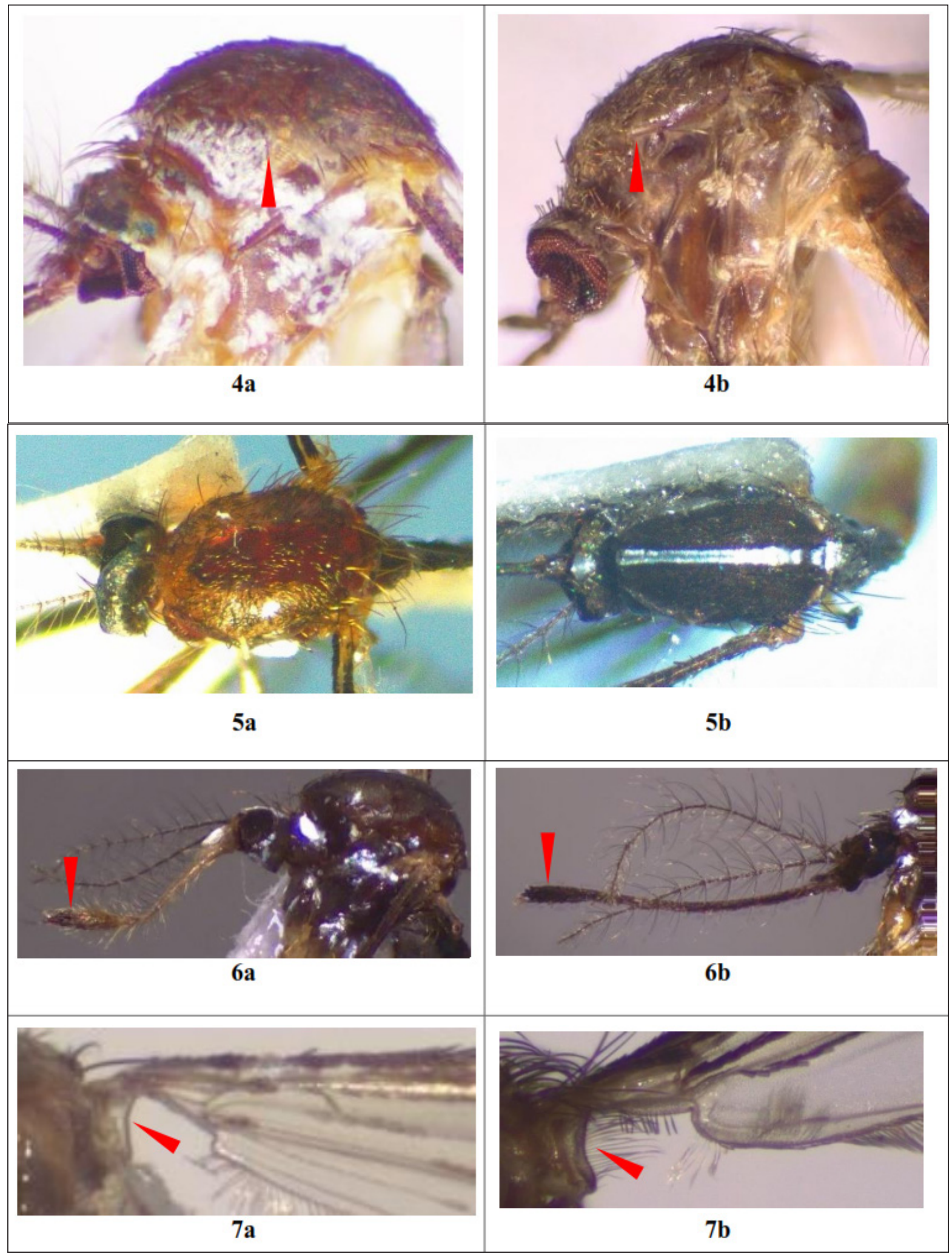

Gambar 1 (Lanjutan). 4a: toraks nyamuk tribe Sabethini; 4b: toraks nyamuk; 5a: skutum nyamuk Tripteroides; 5b: skutum nyamuk; 6a: probosis nyamuk Malaya; 6b: probosis nyamuk Topomyia/ Kimia; 7a: alula sayap gundul; 7b: alula sayap dengan rambut. 


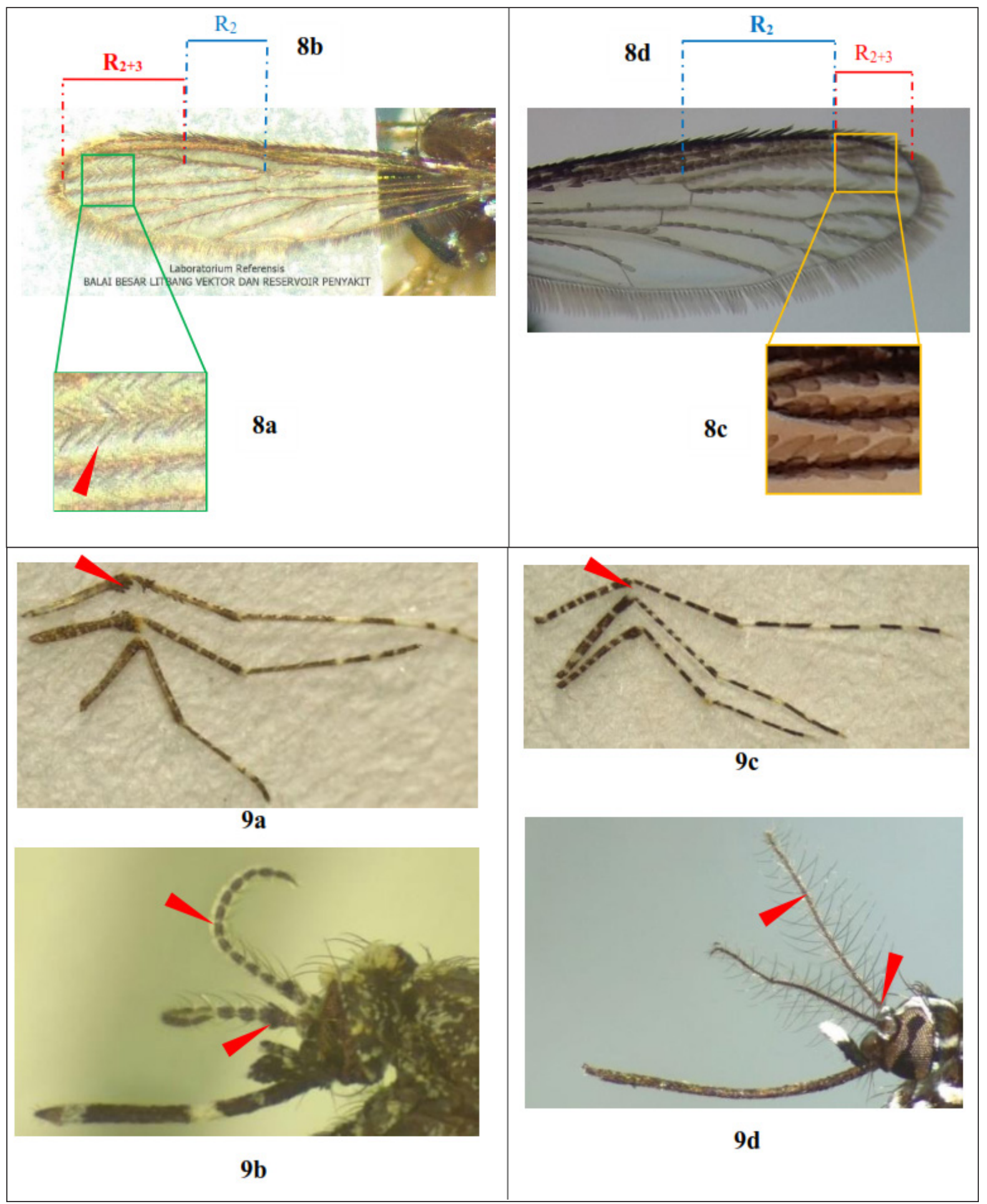

Gambar 1 (Lanjutan). 8a: sisik sayap nyamuk Hodgesia; 8b: sayap nyamuk Hodgesia; 8c: sisik sayap nyamuk; 8d: sayap nyamuk; 9a: kaki nyamuk Aedeomyia; 9b: antena nyamuk Aedeomyia; 9c: kaki nyamuk; 9d: antena nyamuk. 


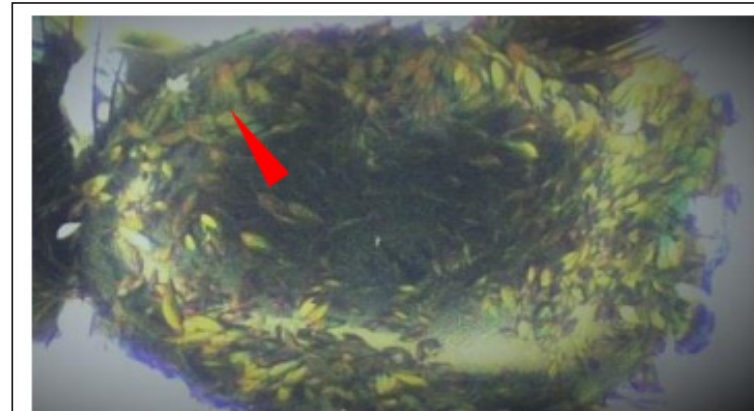

$10 \mathrm{a}$

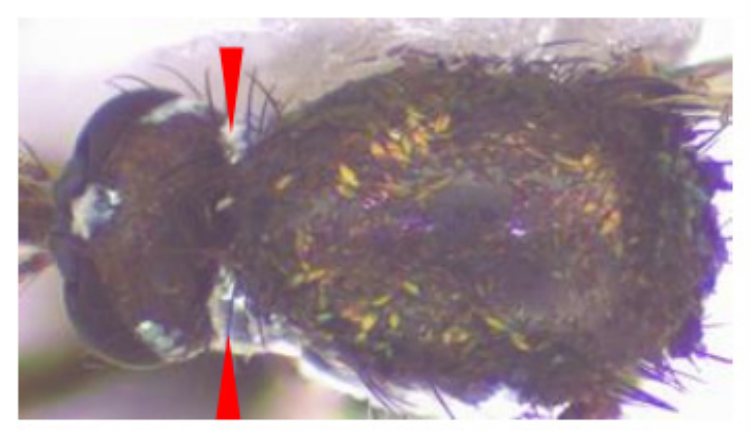

$10 \mathrm{~b}$

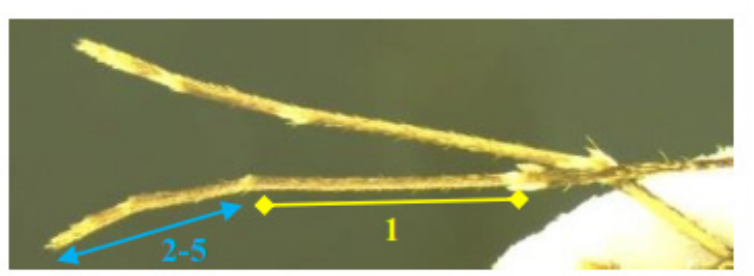

$11 \mathrm{a}$

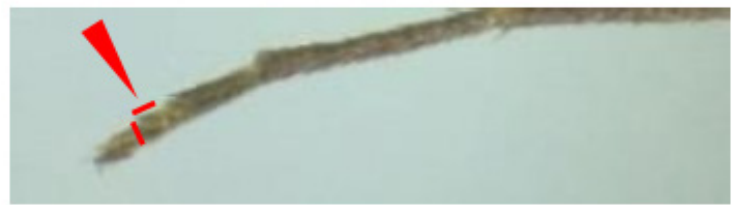

11b

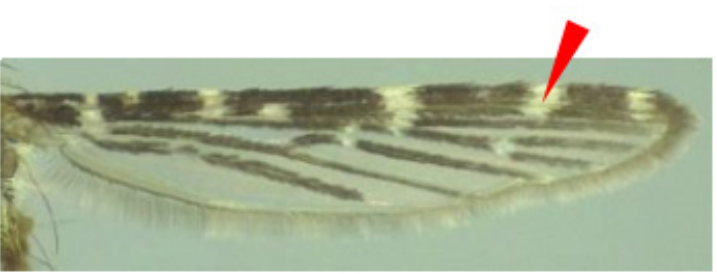

$11 \mathrm{c}$

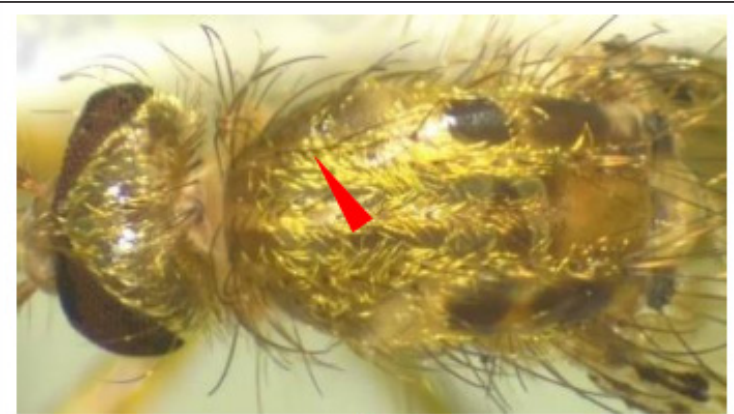

$10 \mathrm{c}$

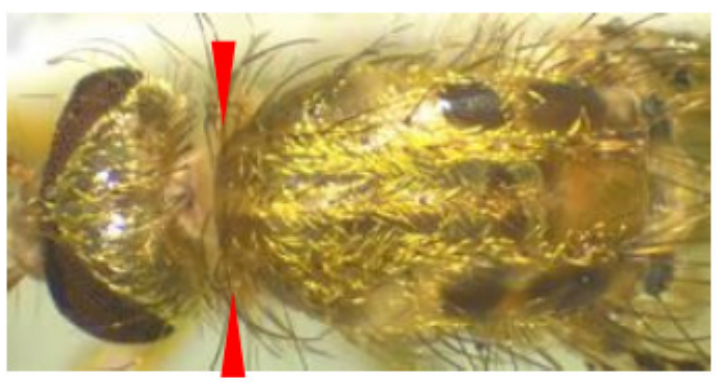

10d

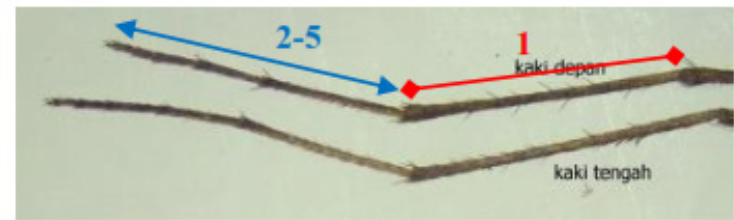

11d

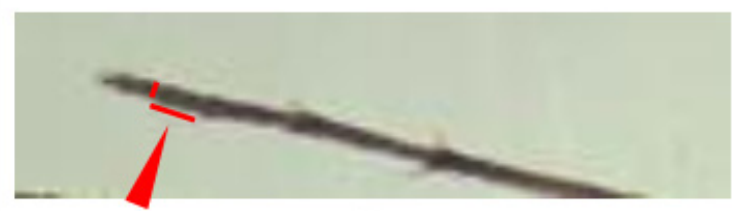

$11 \mathrm{e}$

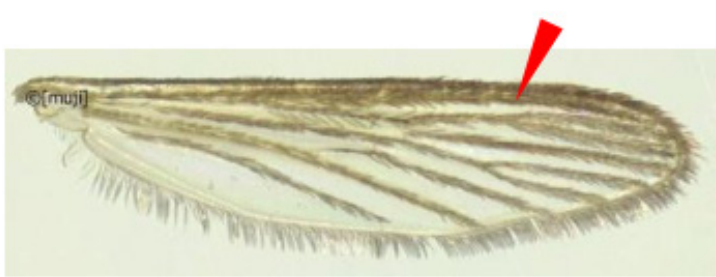

$11 f$

Gambar 1 (Lanjutan). 10a: skutum nyamuk Heizmannia; 10b: antepronotum nyamuk Heizmannia; 10c: skutum nyamuk; 10d: 11a: tibia-tarsus nyamuk Orthopodomyia; 11b: tarsomer 4 nyamuk Orthopodomyia; 11c: sayap nyamuk Orthopodomyia; 11d: tibia-tarsus nyamuk; 11e: tarsomer 4 nyamuk; 11f: sayap nyamuk. 


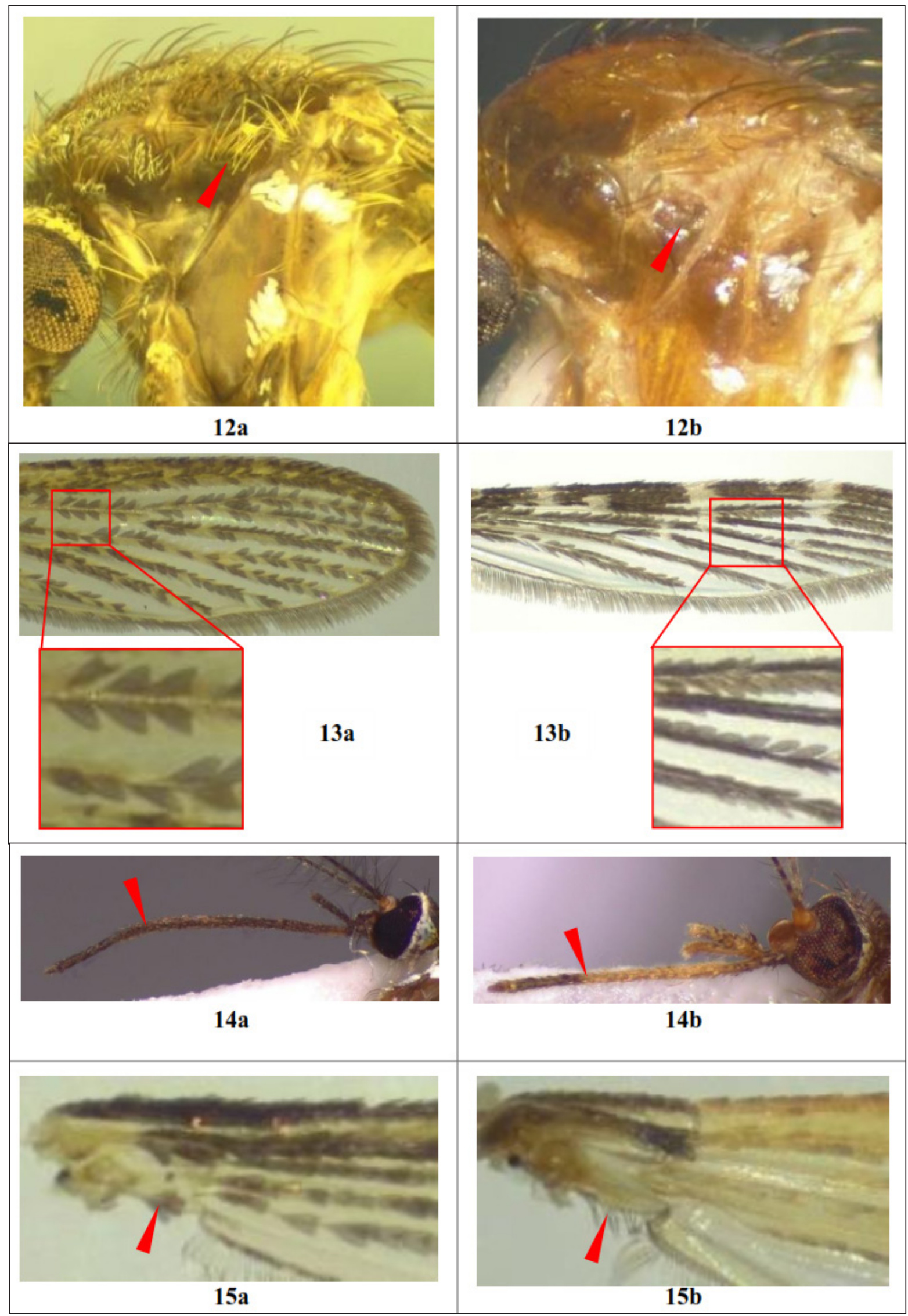

Gambar 1 (Lanjutan). 12a: post-spiracular area dengan rambut; 12b: post-spiracular area tanpa rambut; 13a: sisik sayap nyamuk Mansonia; 13b: sisik sayap nyamuk; 14a: probosis nyamuk Armigeres (Armigeres); 14b: probosis nyamuk; 15a: alula sayap nyamuk Mimomyia; 15 b: alula sayap nyamuk. 
Nugroho \& Mujiyono: Pembaruan informasi taksonomi dan kunci identifikasi nyamuk di Indonesia

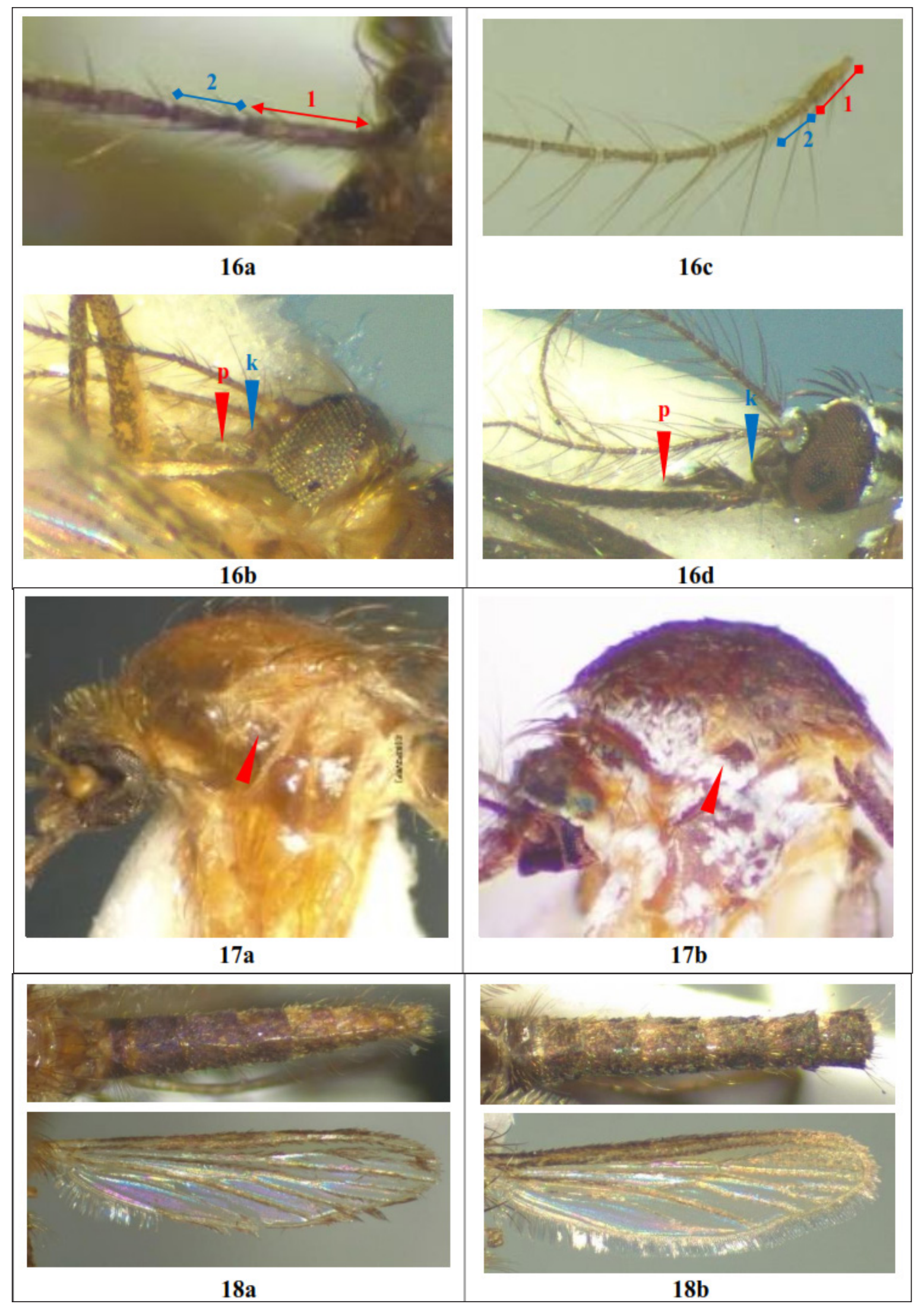

Gambar 1 (Lanjutan). 16a: antena nyamuk Ficalbia; 16b: palpus maksila nyamuk Ficalbia; 16c: antena nyamuk; 16d: palpus maksila nyamuk; 17a: post-spirakel tanpa sisik; 17b: postspirakel dengan sisik; 18a: abdomen dan sayap nyamuk Coquillettidia: 18b: abdomen dan sayap nyamuk. 


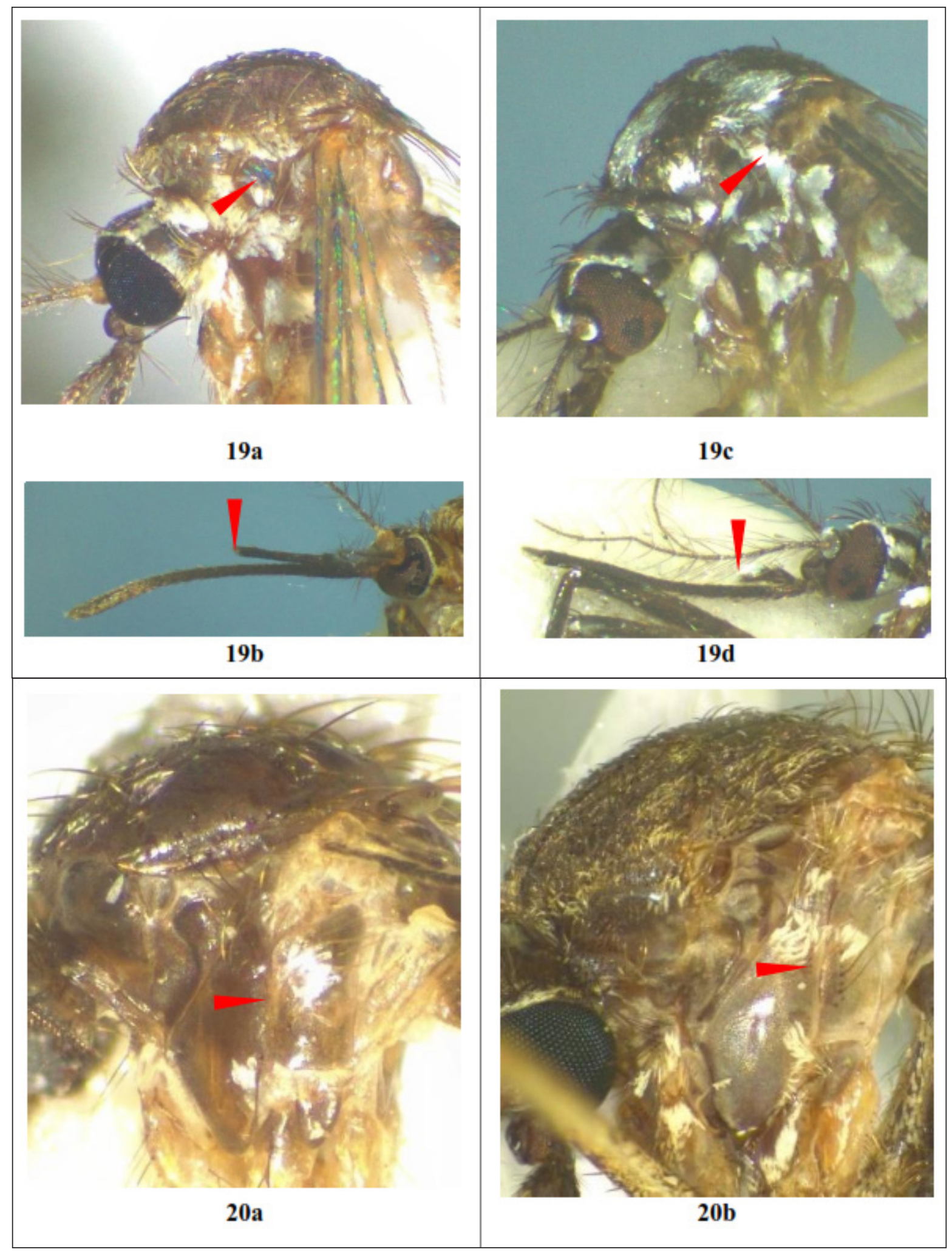

Gambar 1 (Lanjutan). 19a: toraks lateral nyamuk Armigeres (Leicesteria); 19b: probosis-palpus nyamuk Armigeres (Leicesteria); 19c: toraks lateral nyamuk; 19d: probosis-palpus nyamuk; 20a: mesepimeron nyamuk Culex; 20b: mesepimeron nyamuk Lutzia. 


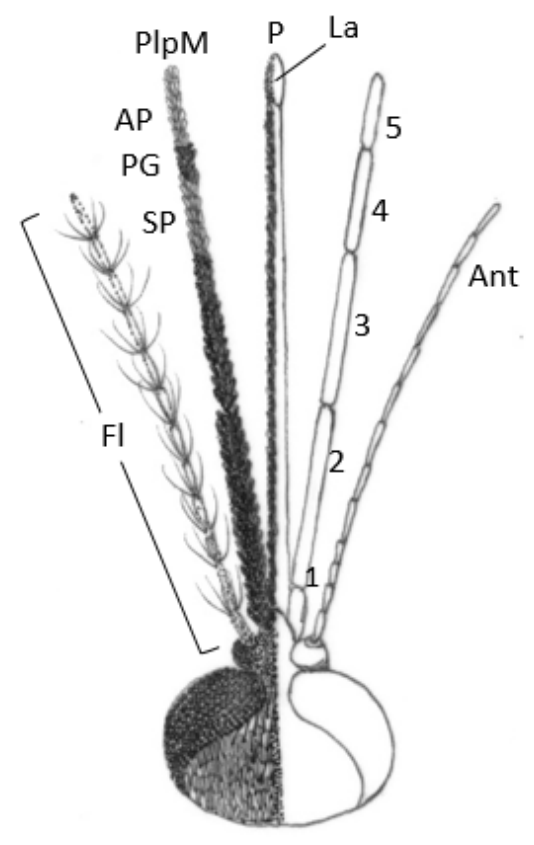

KEPALA
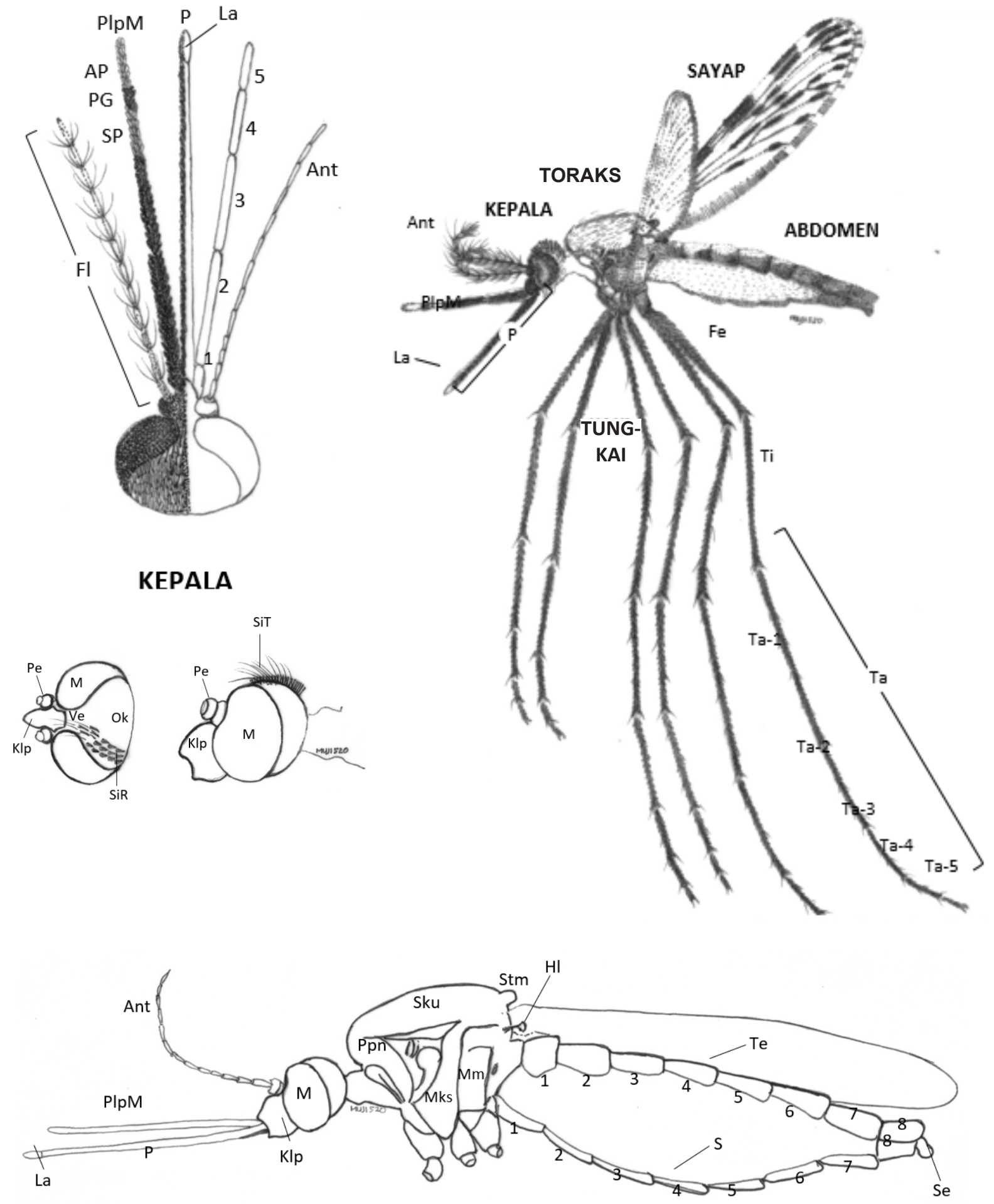

TORAKS - ABDOMEN

Gambar 2. Diagram morfologi tubuh nyamuk. Kepala (Ant: antena; AP: apikal pucat; Fl: flagelum; Klp: klipeus; La: labelum; M: mata majemuk; Ok: oksiput; P: probosis; Pe: pedisel; PG: preapikal gelap; PlpM: palpus maksila; SiR: sisik rebah; SiT: sisik tegak; SP: subapikal pucat; Ve: verteks), Toraks-Abdomen (Ant: antena; Hl: halter; Klp: klipeus; La: labelum; M: mata majemuk; Mks: mesokatepisternum; Mm: mesepimeron; P: probosis; PlpM: palpus maksila; Ppn: posterior pronotum; S: sternit; Se: serkus; Sku: skutum; Stm: skutelum; Te: tergit), dan Tungkai (Fe: femur; Ta: tarsus; Ti: tibia). 


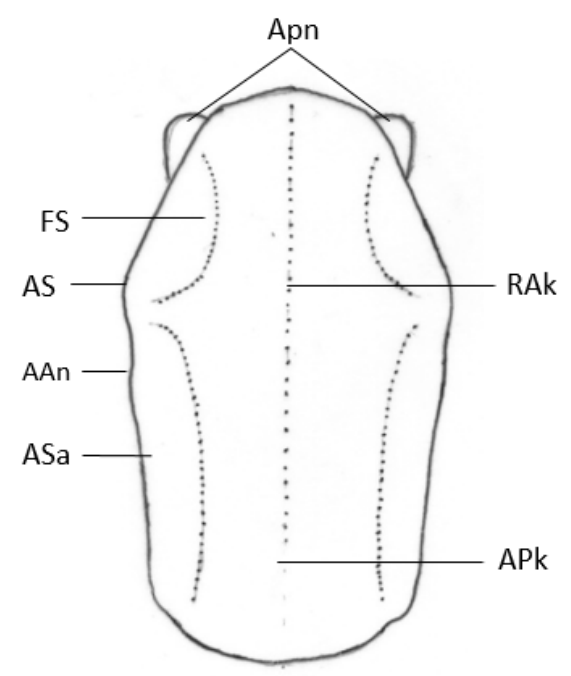

TORAKS DORSAL
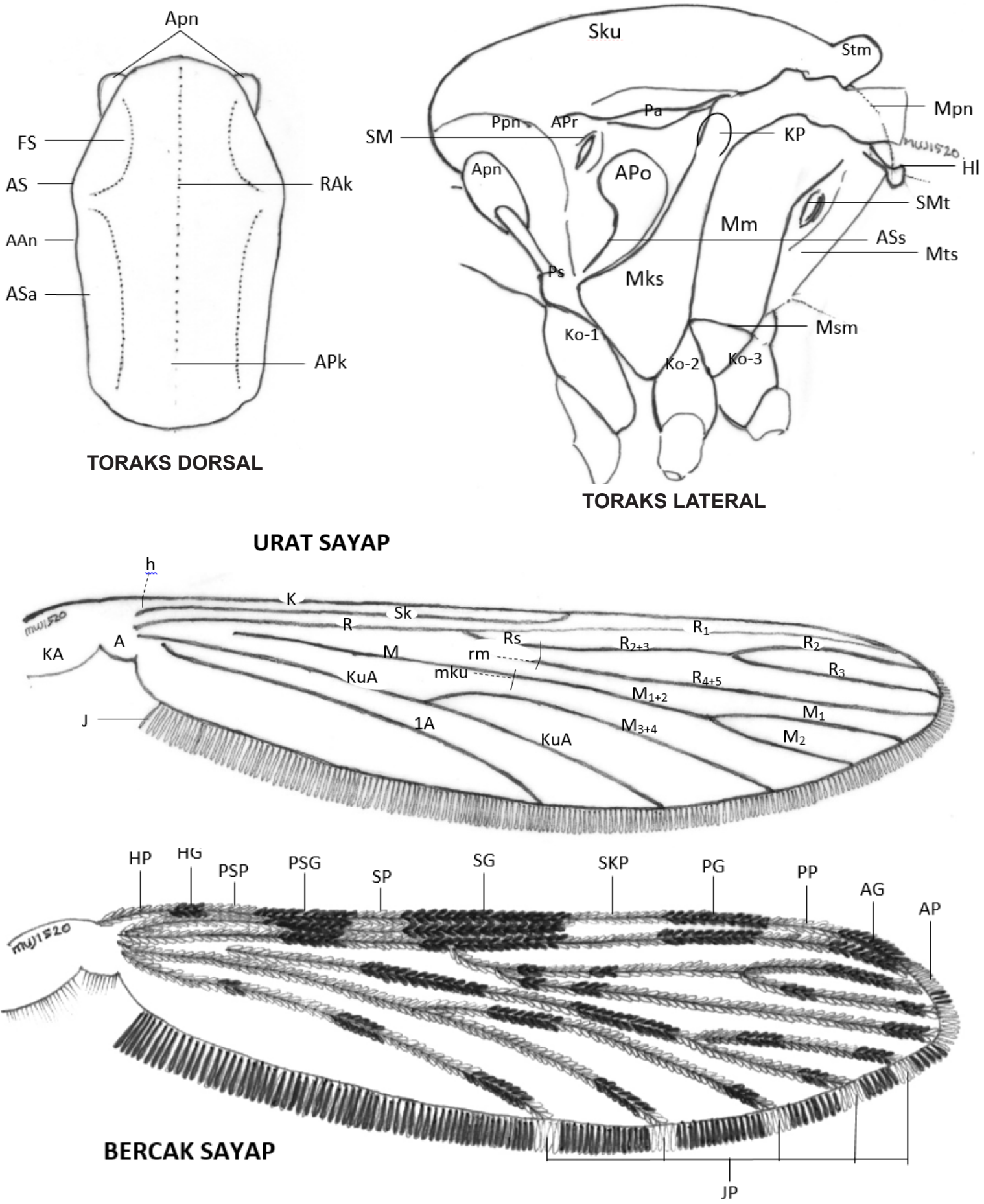

Gambar 3. Diagram morfologi tubuh nyamuk. Toraks dorsal (AAn: area antealar; Apn: anterior pronotum; APk: area preskutelar; ASa: area supraalar; AS: angle skutum; FS: fossa skutum; RAk: rambut akrostikal), Toraks lateral (APo: area postspirakel;Apn: anterior pronotum;APr: area prespirakel; ASs: area subspirakel; Hl: halter; Ko: koksa; KP: knob prealar; Mks: mesokatepisternum; Mm: mesepimeron; Mpn: mesopostnotum; Msm: mesomeron; Pa: paratergit; Ppn: posterior pronotum; Ps: proepisternum; Sku: skutum; SM: spirakel mesothoraks; SMt: spirakel metathoraks; Stm: skutelum), Urat sayap (1A: urat anal; A: alula; h: urat melintang humeral; J: jumbai sayap; K: kosta; KA: kaliptra bagian atas; KuA: urat kubitus anterior; M: urat medial; M1, M2, M1+2, M3+4: urat cabang medial; mku: urat melintang medio kubitus; R: urat radial; R1, R2, R3, R2+3, R4+5: urat cabang radial; rm: urat melintang radio medial; Rs: urat radial sektor; Sk: subkosta), dan Bercak sayap (AG: apikal gelap; AP: apikal pucat; HG: humeral gelap; HP: humeral pucat; JP: jumbai pucat; PG: preapikal gelap; PP: preapikal pucat; PSG: presektor gelap; PSP: presektor pucat; SG: sektor gelap; SP: sektor pucat; SKP: subkosta pucat). 


\section{PEMBAHASAN}

Tribe Toxorhynchitini yang beranggotakan genus tunggal Toxorhynchites mengalami beberapa kali pergantian status di antara tribe dan subfamilia. Pada awalnya Edwards (1932) memperkenalkan tiga tribe dalam Subfamilia Culicinae (true mosquitoes), yaitu Anophelini, Culicini, dan Megarhinini (=Toxorhynchitini). Stone et al. (1959) kemudian menaikkan status tribe Toxorhynchitini menjadi Subfamilia Toxorhynchitinae bersama Subfamilia Anophelinae dan Culicinae. Belkin (1962) menurunkan Toxorhynchitini kembali menjadi tribe dan memecah tribe Culicini menjadi 10 tribe. Kemudian Knight \& Stone (1977) dalam katalog nyamuk dunia mengangkat statusnya kembali menjadi Subfamili Toxorhynchitinae. Perkembangan terbaru, berdasarkan hasil analisis dalam studi filogeninya, Harbach \& Kithching (1998) kembali menurunkan status Toxorhynchitini menjadi tribe.

Tiga subgenus yang tidak lagi tercatat dalam klasifikasi nyamuk Indonesia saat ini, yaitu Subgenus Diceromyia, Verrallina, dan Lutzia. Satu spesies anggota Subgenus Diceromyia di Indonesia, yaitu Aedes iyengari Edwards dipindahkan subgenusnya dan menjadi spesies tipe dalam Subgenus Petermattinglyius (Reinert et al. 2009). Subgenus Verrallina dan Lutzia keduanya berubah status menjadi genus (Reinert 1999; Tanaka 2003). Genus Verrallina terbagi ke dalam tiga subgenus, yaitu Harbachius (1 spesies), Neomacleaya (13 spesies), dan Verrallina (19 spesies). Indonesia memiliki spesies yang termasuk dalam tiga subgenus tersebut (Nugroho et al. 2019). Genus Lutzia juga terbagi ke dalam tiga subgenus, yaitu Lutzia, Insulalutzia, dan Metalutzia. Indonesia hanya memiliki Subgenus Metalutzia dengan dua spesies anggotanya, yaitu Lutzia fuscana (Wiedemann) dan Lutzia halifaxii (Theobald).

Selain Verrallina dan Lutzia yang muncul sebagai genus baru, pada tahun 2007 Genus Kimia dideskripsikan oleh Harbach, Duc Huong \& Kitching dengan spesies tipe Kimia decorabilis (Leicester). Genus Kimia adalah kelompok spesies nyamuk homogen kecil dari wilayah Oriental sebelah timur. Sebelumnya, spesies nyamuk dalam Genus Kimia merupakan anggota dari Subgenus
Suaymia dalam Genus Topomyia (Harbach et al. 2007). Anggota spesies dalam Genus Kimia yang terdapat di Indonesia antara lain adalah Kimia decorabilis (Leicester) dan Kimia miyagii (Toma \& Mogi).

Perkembangan klasifikasi juga terjadi dalam genus besar Culex dan satu genus dalam tribe Sabethini, yaitu Tripteroides. Pada Genus Culex terdapat penambahan satu subgenus, yaitu Subgenus Oculeomyia. Subgenus Oculeomyia dalam Genus Culex beranggotakan kelompok spesies yang sebelumnya berada dalam Bitaeniorhynchus subgroup, Sitiens group, Subgenus Culex. Anggota spesies dalam Subgenus Oculeomyia antara lain Culex bitaeniorhynchus (Giles), Culex sinensis Theobald dan kerabatnya. Alasan munculnya Subgenus Oculeomyia adalah karena karakter maksila dan mandibula larva $C x$. bitaeniorhynchus dan $C x$. sinensis sangat berbeda tidak hanya dengan spesies lain dalam subgenus Culex, namun juga dengan semua spesies dari subgenus lain dalam genus Culex. Sebelumnya Theobald (1907) mendirikan Genus Oculeomyia sebagai nama genus untuk spesies Culex sarawaki Theobald yang kemudian diturunkan statusnya menjadi sinonim untuk $C x$. bitaeniorhynchus oleh Edwards (1913). Itulah dasarnya dapat digunakan nama Oculeomyia sebagai nama subgenus baru untuk $C x$. bitaeniorhynchus dan $C x$. sinensis (Tanaka et al. 1979).

Penataan klasifikasi dalam Genus Tripteroides dilakukan oleh Mattingly (1980). Salah satunya adalah mengangkat kembali status Subgenus Polylepidomyia dari sinonimnya dengan Subgenus Rachionotomyia. Masih dalam artikel yang sama, Mattingly mendirikan subgenus baru bernama Tricholeptomyia beranggotakan spesies tidak berornamen yang terdapat di Filipina. Saat ini dikenal lima subgenus dalam Genus Tripteroides, yaitu Polylepidomyia, Rachionotomyia, Rachisoura, Tricholeptomyia, dan Tripteroides. Spesies anggota Subgenus Polylepidomyia adalah semua spesies yang sebelumnya termasuk dalam Subgenus Rachionotomyia yang tersebar di wilayah Australasia. Maka spesies anggota Subgenus Rachionotomyia yang tersisa terbatas hanya di wilayah Oriental (Mattingly 1981).

Reinert, Harbach, dan Kitching telah membangun sistem klasifikasi modern untuk tribe 
Aedini. Perkembangan taksonomi dalam Genus Aedes terjadi sangat pesat dalam kurun waktu tahun 2004-2009 dan berhasil memunculkan 74 genus dari genus komposit Aedes. Perubahan pertama adalah naiknya status Subgenus Verrallina menjadi genus pada tahun 1999, kemudian dilanjutkan dengan naiknya status Subgenus Ayurakitia dan Ochlerotatus menjadi genus (Reinert 2000a; 2000b). Kemudian melalui empat tahap studi filogenetik terhadap tribe Aedini muncul genus baru maupun genus yang berasal dari perubahan status subgenus dari Genus Aedes. Total terdapat 27 genus yang muncul dari perkembangan taksonomi dalam kurun waktu tersebut di Indonesia yang rinciannya dijelaskan berikut ini. Tahap pertama pada tahun 2004 naik status menjadi genus sebanyak 15 subgenus, yaitu Alanstonea, Christephersiomyia, Downsiomyia, Edwardsaedes, Finlaya, Geoskusea, Huaedes, Leptosomatomyia, Lorrainea, Mucidus, Neomelaniconion, Paraedes, Rhinoskusea, Scutomyia, dan Stegomyia (Reinert et al. 2004). Tahap kedua pada tahun 2006 naik menjadi genus sebanyak lima subgenus, yaitu Bruceharrisonius, Hulecoeteomyia, Macleaya, Phagomyia, dan Pseudoskusea, serta tiga genus baru, yaitu Collesius, Patmarksia, dan Rampamyia (Reinert et al. 2006). Tahap ketiga pada tahun 2008 naik menjadi genus satu subgenus, yaitu Danielsia (Reinert et al. 2008). Lalu tahap keempat pada tahun 2009 naik menjadi genus sebanyak dua subgenus, yaitu Aedimorphus dan Cancraedes, serta satu genus baru, yaitu Petermattinglyius (Reinert et al. 2009).

Pada tahun 2015, Wilkerson et al. (2015) melakukan analisis ulang terhadap klasifikasi modern tribe Aedini yang diusulkan oleh Reinert et al. (2009). Wilkerson et al. (2015) mengusulkan penyederhanaan kembali pengelompokan Genus Aedes yang bertujuan 1) mengembalikan sistem klasifikasi yang bermanfaat untuk komunitas operasional; 2) meningkatkan kemampuan taksonom dalam menempatkan spesies baru ke dalam suatu genus secara akurat; 3) memelihara kemajuan menuju klasifikasi alami berdasarkan kelompok spesies yang monofiletik; dan 4) memperbaiki klasifikasi yang menyebabkan ketidakstabilan ketika adanya deskripsi spesies baru dan spesies yang sudah ada dideskripsikan lebih terperinci (Wilkerson et al. 2015). Wilkerson et al. (2015) menurunkan kembali genus dan subgenus yang diusulkan oleh Reinert et al. (2009) sejak tahun 2000 menjadi berturutturut subgenus dan kelompok spesies informal (informal species group) untuk menjaga stabilitas klasifikasi ketika tersedia data taksonomi baru. Klasifikasi ini dikenal sebagai klasifikasi Aedini tradisional yang telah dimodifikasi (Wilkerson et al. 2015). Seluruh genus diturunkan kembali menjadi subgenus, kecuali Verrallina dengan status tetap sebagai genus. Perubahan tersebut menjadikan Genus Aedes di dunia terbagi dalam 74 subgenus, sedangkan di Indonesia tercatat ada 28 subgenus. Sistem klasifikasi versi Reinert et al. (2009) dan Wilkerson et al. (2015) keduanya tetap berlaku, namun penggunaan sistem klasifikasi nyamuk tribe Aedini versi Wilkerson et al. (2015) lebih sederhana dan mudah dipahami secara luas, khususnya berkaitan dengan implementasi informasi mengenai keanekaragaman nyamuk dalam fungsinya sebagai pendukung upaya pengendalian nyamuk vektor.

\section{KESIMPULAN}

Berdasarkan perkembangan taksonomi nyamuk terbaru saat ini Indonesia memiliki 21 genus dan 63 subgenus. Penambahan yang terjadi sejak daftar spesies nyamuk tahun 1981 adalah tiga genus dan 15 subgenus. Perubahan paling besar terjadi pada Genus Aedes dengan munculnya Verrallina sebagai genus dan bertambahnya 12 subgenus dalam Genus Aedes. Dua genus lain yang muncul adalah Lutzia dari Genus Culex dan Kimia dari Genus Topomyia. Saat ini terdapat dua sistem klasifikasi dalam tribe Aedini, yaitu klasifikasi modifikasi versi Reinert et al. dan klasifikasi tradisional versi Wilkerson et al. Kedua sistem klasifikasi tersebut saat ini berlaku, namun penulis mengusulkan agar entomolog di Indonesia menggunakan sistem klasifikasi nyamuk dalam tribe Aedini versi Wilkeson et al. karena lebih sederhana. 


\section{UCAPAN TERIMA KASIH}

Penulis mengucapkan terima kasih kepada Kepala B2P2VRP Salatiga telah mengijinkan penulis menggunakan spesimen tersimpan di biorepositori nyamuk B2P2VRP Salatiga untuk pembuatan kunci identifikasi fotografis dalam artikel ini. Terima kasih kepada rekan-rekan laboratorium koleksi referensi vektor penyakit B2P2VRP Salatiga yang telah mendukung dan banyak membantu dalam penyusunan kunci identifikasi maupun penulisan artikel ini.

\section{DAFTAR PUSTAKA}

Belkin J. 1962. The Mosquitoes of the South Pasific (Diptera, Culicidae). Los Angeles: University of California Press.

Ditjen PP\&PL Depkes RI. 2008a. Kunci Identifikasi Nyamuk Aedes. Jakarta: Depkes RI.

Ditjen PP\&PL Depkes RI. 2008b. Kunci Identifikasi Nyamuk Culex. Jakarta: Depkes RI.

Ditjen PP\&PL Depkes RI. 2008c. Kunci Identifikasi Nyamuk Mansonia. Jakarta: Depkes RI.

Edwards FW. 1913. New synonymy in oriental Culicidae. Bulletin of Entomological Research. 221-242. doi: https://doi.org/10.1017/ S0007485300043133.

Edwards FW. 1932. Genera Insectorum. Diptera. Family Culicidae. Fascicule. Tervueren.

Harbach RE, Knight KL. 1980. Taxonomists' Glossary of Mosquito Anatomy. Raleigh: North Carolina State University.

Harbach RE, Kithching I. 1998. Phylogeny and classification of the Culicidae (Diptera). Systematic Entomology 23:327-370. doi: https:// doi.org/10.1046/j.1365-3113.1998.00072.x.

Harbach RE, Huong VD, Kitching IJ. 2007. Systematics of Kimia, a new genus of Sabethini (Diptera: Culicidae) in the Oriental Region. Proceedings of the Entomological Society of Washington 109:102-120.

Knight K, Stone A. 1977. A Catalog of The Mosquitoes in the World. College Park, Maryland: Entomological Society of America.

Lohman DJ, de Bruyne M, Page T, von Rintelen K, Hall R, Ng PKL, Shih H-T, Carvalho GR, Rintelen Tv. 2011. Biogeography of the IndoAustralian Archipelago. Annual Review of Ecology, Evolution, and Systematics 42:205226. doi: https://doi.org/10.1146/annurevecolsys-102710-145001.
Mattingly PF. 1980. An interim reclassification of the Genus Tripteroides with particular reference to the Australasian subgenera. Mosquito Systematics 12:164-171.

Mattingly PF. 1981. The Subgenera Rachionotomyia, Tricholeptiomyia and Tripteroides (Mabinii Group) of Genus Tripteroides in the Oriental Region (Diptera: Culicidae). Contribution of the American Entomological Institute 17:1-147.

Nugroho SS, Mujiono, Setiyaningsih R, Garjito TA, Ali RSM. 2019. Daftar spesies dan data distribusi terbaru nyamuk Aedes dan Verrallina (Diptera: Culicidae) di Indonesia. Jurnal Vektor dan Reservoir Penyakit 11:111-120. doi: https:// doi.org/10.22435/vk.v11i2.1462.

O'Connor CT, Soepanto A. 1999. Kunci Bergambar Nyamuk Anopheles di Indonesia. Jakarta: Ditjen P2M \& PLP.

O'Connor CT, Sopa T. 1981. A Checklist of The Mosquitoes of Indonesia. U.S. Naval Medical Research Unit No. 2. NAMRU-SP-4., Vol. 7. Jakarta: U.S. Naval Medical Research Unit No. 2 Jakarta, Indonesia.

Rattanarithikul R, Harbach RE, Harrison BA, Panthusiri P, Coleman RE, Richardson JH. 2010. Illustrated keys to the mosquitoes of Thailand VI. Tribe Aedini. The Southeast Asian Journal of Tropical Medicine and Public Health. 41:57-64.

Rattanarithikul R, Harbach RE, Harrison BA, Panthusiri P, Jones JW, Coleman RE. 2005b. Illustrated Keys to the Mosquitoes of Thailand II. Genera Culex and Lutzia. The Southeast Asian Journal of Tropical Medicine and Public Health. 36:6-31.

Rattanarithikul R, Harrison BA, Harbach RE, Panthusiri P, Coleman RE. 2006b. Illustrated keys to the mosquitoes of Thailand IV. Anopheles. The Southeast Asian Journal of Tropical Medicine and Public Health 37:9-36.

Rattanarithikul R, Harrison BA, Panthusiri P, Peyton EL, Coleman RE. 2006a. Illustrated keys to the mosquitoes of Thailand III. Genera Aedeomyia, Ficalbia, Mimomyia, Hodgesia, Coquillettidia, Mansonia, and Uranotaenia. The Southeast Asian Journal of Tropical Medicine and Public Health 37:16-17.

Rattanarithikul R, Harbach RE, Harrison BA, Panthusiri P, Coleman RE. 2007. Illustrated keys to the mosquitoes of Thailand: V. Genera Orthopodomyia, Kimia, Malaya, Topomyia, Tripteroides, and Toxorhynchites. The Southeast Asian Journal of Tropical Medicine and Public Health 38:1-65. 
Rattanarithikul R, Harrison BA, PanthusiriP, Coleman RE. 2005a. Illustrated keys to the mosquitoes of Thailand: I. Background; geographic distribution; lists of genera, subgenera, and species; and a key to the genera. The Southeast Asian Journal of Tropical Medicine and Public Health 36:1-80.

Reinert JF. 1999. Restoration of Verrallina to generic rank in Tribe Aedini (Diptera: Culicidae) and descriptions of the genus and three included subgenera. Contributions of the American Entomological Institute 31:1-83.

Reinert JF. 2000a. Restoration of Ayurakitia to generic rank in tribe Aedini and a revised definition of the genus. Journal of the American Mosquito Control Association 16:57-65.

Reinert JF. 2000b. New classification for the composite Genus Aedes (Diptera: Culicidae: Aedini), elevation of subgenus Ochlerotatus to generic rank, reclassification of the other subgenera, and notes on certain subgenera and spesies. Journall of the American Mosquito Control Association 16:175-188.

Reinert JF, Harbach RE, Kitching IJ. 2004. Phylogeny and classification of Aedini (Diptera: Culicidae), based on morphological characters of all life stages. Zoological Journal of the Linnean Society 142:289-368. doi: https://doi. org/10.1111/j.1096-3642.2004.00144.x.

Reinert JF, Harbach RE, Kitching IJ. 2006. Phylogeny and classification of Finlaya and allied taxa (Diptera: Culicidae: Aedini) based on morphological data from all life stages. Zoological Journal of the Linnean Society 142:289-368. doi: https://doi.org/10.1111/ j.1096-3642.2004.00144.x.

Reinert JF, Harbach RE, Kitching IJ. 2008. Phylogeny and classification of Ochlerotatus and allied taxa (Diptera: Culicidae: Aedini), based on morphological characters from all life stages. Zoological Journal of the Linnean Society 142:289-368. doi: https://doi.org/10.1111/ j.1096-3642.2004.00144.x.
Reinert JF, Harbach RE, Kitching IJ. 2009. Phylogeny and classification of tribe Aedini (Diptera: Culicidae). Zoological Journal of the Linnean Society 157:700-794. doi:10.1111/ j.1096-3642.2009.00570.x. doi: https://doi. org/10.1111/j.1096-3642.2009.00570.x.

Stojanovich CJ, Scott HG. 1966. Illustrated Key to Mosquitoes of Vietnam. Atlanta, Georgia: U.S. Department of Health, Education, and Welfare.

Stojanovich CJ, Scott HG. 1965a. Illustrated to Culex Mosquitoes of Vietnam. Atlanta, Georgia: U.S. Department of Health, Education, and Welfare.

Stojanovich CJ, Scott HG. 1965b. Illustrated to Aedes mosquitoes of Vietnam. Atlanta, Georgia: U.S. Department of Health, Education, and Welfare.

Stone A, Knight K, Starcke H. 1959. A Synoptic Catalog of the Mosquitoes of The World (Diptera, Culicidae). College Park, Maryland: Entomological Society of America.

Tanaka K. 2003. Studies on the pupal mosquitoes of Japan (9) Genus Lutzia, with establishment of two new subgenera, Metalutzia and Insulalutzia (Diptera, Culicidae). Japanese Journal of Systematic Entomology 9:159-169.

Tanaka K, Mizusawa K, Saugstad ES. 1979. A revision of the adult and larval mosquitoes of Japan (Including the Ryukuu Archipelago and the Ogasawara Islands) and Korea (Diptera: Culicidae). Contribution of the American Entomological Institute 16:1-987.

Theobald FV. 1907. A Monograph of the Culicidae of the World - Part IV. The British Museum. General No. London: Order of the Trustees.

Wilkerson RC, Linton YM, Fonseca DM, Schultz TR, Price DC, Strickman DA. 2015. Making mosquito taxonomy useful: A stable classification of tribe Aedini that balances utility with current knowledge of evolutionary relationships. PLoS ONE 10:1-26. doi: https://doi.org/10.1371/ journal.pone. 0133602 . 